\title{
Catastrophization is related to the patient and not to the severity of migraine
}

\author{
Catastrofização se relaciona ao paciente e não à gravidade da enxaqueca \\ Eduardo Almeida Guimarães NOGUEIRA',2, Flavia Rodrigues de OLIVEIRA ${ }^{3}$, Vitor Martinez de CARVALHO4, \\ Carina TELAROLLI ${ }^{5}$, Yara Dadalti FRAGOSO ${ }^{1,4}$
}

\begin{abstract}
Background: Catastrophization is a psychological aspect of pain that alters its perception and expression. Objective: To investigate the feature of catastrophization in migraine. Methods: An online survey of individuals suffering from migraine attacks at least twice a month, for at least one year was carried out. Confidentiality was assured and participants gave details of their headache (including a visual analogue pain scale) and answered the Hospital Anxiety and Depression Scale and the Catastrophization Scale questionnaires. Results: The survey included 242 individuals with migraine attacks at least twice a month. The median scores observed in this group of individuals were 7 for pain, 11 for anxiety, 7 for depression, and 2 for catastrophization. Catastrophization had no correlation with the duration $(p=0.78)$ or intensity $(p=0.79)$ of the migraine. There was no correlation between catastrophization and headache frequency ( $p=0.91)$ or the monthly amount of headache medication taken ( $p=0.85$ ). High scores for catastrophization (3.0) were identified in one third of the participants. These high scores were not associated with age, headache duration, pain severity, frequency of attacks, or traits of depression or anxiety. There was a moderate association between both depression and anxiety traits with catastrophization. Conclusions: Catastrophization seems to be a trait of the individual and appears to be unrelated to the characteristics of the migraine.
\end{abstract}

Keywords: Headache; Migraine; Catastrophization; Pain.

\section{RESUMO}

Antecedentes: A catastrofização é um aspecto psicológico da dor, alterando sua percepção e expressão. Objetivos: Investigar o fenômeno da catastrofização na enxaqueca. Métodos: Pesquisa online com indivíduos que sofrem de crises de enxaqueca pelo menos duas vezes por mês, por pelo menos um ano. O sigilo foi assegurado. O participante dava detalhes de sua dor de cabeça (incluindo escala de dor analógica visual) e respondeu à Escala de Ansiedade e Depressão Hospitalar e à Escala de Catastrofização. Resultados: A pesquisa identificou 242 indivíduos com ataques de enxaqueca pelo menos duas vezes por mês. Os escores medianos observados neste grupo de indivíduos foram 7 para dor, 11 para ansiedade, 7 para depressão e 2 para catastrofização. Catastrofização não teve correlação com a duração ( $p=0,78$ ) ou intensidade $(p=0,79)$ da dor na crise de enxaqueca. Não houve correlação entre catastrofização e frequência de crises ( $p=0,91)$ ou quantidade mensal de medicação usada para tratar a cefaleia $(p=0,85)$. Foram identificados escores elevados para catastrofização $(3,0)$ em um terço dos participantes. Esses escores elevados não foram associados à idade, duração da dor de cabeça, gravidade da dor, frequência de ataques e traços de depressão ou de ansiedade. Houve moderada associação entre casos com concomitante depressão e ansiedade e catastrofização. Conclusões: A catastrofização parece ser um traço do indivíduo e parece não estar relacionada às características da enxaqueca.

Palavras-chave: Cefaleia; Enxaqueca; Catastrofização; Dor.

\footnotetext{
'Universidade Metropolitana de Santos, MS \& Headache Research, Santos SP, Brazil.

${ }^{2}$ Hospital Beneficencia Portuguesa de Santos, Santos SP, Brazil.

${ }^{3}$ Universidade Metropolitana de Santos, Faculdade de Medicina, Santos SP, Brazil.

«Universidade Metropolitana de Santos, Programa de Pós-graduação em Saúde e Meio Ambiente, Santos SP, Brazil.

${ }^{5}$ Universidade Federal de São Carlos, São Carlos SP, Brazil.

EAGN (D) https://orcid.org/0000-0002-6035-560X; FRO (D) https://orcid.org/0000-0003-3371-3683; VMC (DD https://orcid.org/0000-0001-6220-877X;

CT (1D) https://orcid.org/0000-0001-6627-9698;YDF (1D) https://orcid.org/0000-0001-8726-089X

Correspondence:Yara Dadalti Fragoso; Email:yara@bsnet.com.br.

Conflict of interest: There is no conflict of interest to declare.

Authors' contribution: EGN: study design, supervision, data collection and analyses; FRO: data collection, discussion of results; VMC: data collection, discussion of results; CT: study design, discussion of results; YDF: lead study design, lead supervision, data analyses and writing the manuscript.

Received on October 01, 2020; Received in its final form on November 09, 2020; Accepted on November 10, 2020.
} 


\section{INTRODUCTION}

Primary headaches are a frequent reason for seeking medical care. While some patients may deal well with their headache attacks, others accumulate anxiety, depression, and other psychological features to their chronic and/or recurrent pain. Some patients may have cephalalgiaphobia ${ }^{1}$, i.e. the fear of developing a headache, while others can catastrophize their condition².

Catastrophizing is a psychological process involving a maladaptive and negative evaluation of specific symptoms. When a person catastrophizes, the process can contribute to increase the intensity of that symptom and increase the degree of emotional distress ${ }^{3}$. Psychological aspects, which can alter the perception and expression of pain, pose extra challenges to a patient's medical consultation and follow-up ${ }^{4}$. While headache specialists may find it easier to identify these psychological patterns in their daily practice, general clinicians may not be familiar with these difficult cases. When searching for information in the medical literature, general practitioners will often find reports on catastrophization from tertiary headache clinics ${ }^{5}$.

The aim of the present study was to investigate the prevalence and level of catastrophization in people with headache in the general population using an online survey. This assessment may provide a broader picture of the situation that general clinicians experience while attending patients with primary headaches.

\section{METHODS}

Prior to data collection, this study was approved by the Ethics Committee of the Universidade Metropolitana de Santos, SP, Brazil. Participants accessed an initial page of the survey containing the informed consent statement. Once the terms of the survey had been accepted, the participant could start answering the questions. The sample size was calculated as 168 individuals, for a $95 \%$ confidence interval, and was based on previously reported levels of catastrophization in migraine ${ }^{5}$.

The study was announced via social media and the survey remained open from July 28th to August 3rd, 2020. Eligible participants were those that had a minimum of two migraine episodes per month for at least one year. If the sample size had not been reached within this period, the collection period would be extended. Diagnosis of migraine was confirmed by a set of questions based on the International Headache Society criteria ${ }^{6}$. After answering these questions, if the participant fulfilled the criteria for migraine, a new page would open with questions for anxiety, depression, and catastrophization screening.

While propagating the study within social media (Facebook and Instagram), it was clearly stated that only migraineurs should participate, with either a diagnosis of migraine or conclusion that migraine was the diagnosis by reading the headache characteristics. The study was advertised as assessing "some psychological aspects of migraineurs" and, at no time, catastrophization was mentioned.

The following data were gathered: gender, age, educational level, headache characteristics (to make sure that it was a migraine), and participants answered the Hospital Anxiety and Depression Scale $(\mathrm{HAD})^{7}$ and the Catastrophization Scale ${ }^{9}$, both validated for use in Portuguese ${ }^{8,10}$. The HAD contains alternate questions relating to anxiety and depression that are counted separately. Scores above 13 for anxiety and/or depression are suggestive of moderate to severe traits of either or both. The catastrophization scale contains 13 questions that are scored from zero to four; the results are summed and divided by 13 . Higher total scores are associated with higher degrees of catastrophization. In addition, headache characteristics were investigated to confirm that they were typical of migraine. The participants were also given a visual scale scored from zero to 10 on which they marked their usual intensity of headaches.

Statistical analyses were performed using GraphPad Prism. After confirming the normality of the data using the Kolmogorov-Smirnov test, the authors used Student's t test, Fisher's exact test, and Pearson's correlation for comparisons between groups. Results are presented as median values within the interquartile range (25 to $75 \%$ ). Correlations between parameters were expressed as $\mathrm{p}$ values, obtained from the original $r$ value. Statistically significant values were those with $\mathrm{p}<0.05$.

\section{RESULTS}

The survey was answered by 246 individuals who reported having headaches at least twice a month. Four of them did not fulfill the diagnostic criteria for migraine from the International Headache Society ${ }^{6}$ and were excluded.

The participants comprised 233 women and nine men, with median age of 22 years; $96 \%$ of them had had at least 12 years of formal education. The median scores observed in this group of individuals were 7 for pain, 11 for anxiety, 7 for depression, and 2 for catastrophization. High scores for catastrophization $(\geq 3.0)$ were identified in $32.5 \%$ of the participants.

Most of the patients (68.6\%) had had over five years of headache history. Most participants (55.3\%) had headaches on fewer than 14 days per month. The anxiety, depression, and catastrophization scores did not show any correlation with the duration or frequency of headache. The migraines of 166 individuals were without aura, while 65 had visual auras, nine had paresthesia as the aura, and two had mixed forms, including dysphasia. There was no correlation between migraine with or without aura and catastrophization ( $\mathrm{p}=0.97)$. 
Likewise, there was no correlation between the patients' age and catastrophization $(\mathrm{p}=0.95)$.

The duration of an headache episode was between four hours and three days for $72.3 \%$ of the participants. The remaining individuals had continuous or nearly continuous headache. Catastrophization had no correlation with the duration $(p=0.78)$ or intensity $(p=0.79)$ of the migraine. There was no correlation between catastrophization and headache frequency $(p=0.91)$ or the monthly amount of headache medication taken $(\mathrm{p}=0.85)$.

Anxiety traits were identified in $66.5 \%$ of all participants, while depression traits were observed in $37.6 \%$ of them. There was a strong correlation between anxiety and depression $(\mathrm{p}=0.007 ; \mathrm{r}=0.71)$. Neither of these conditions had any correlation with catastrophization: $\mathrm{p}=0.21$ for anxiety and $\mathrm{p}=0.31$ for depression traits. However, for patients with traits of both anxiety and depression, a moderate correlation was observed $(\mathrm{p}=0.04 ; \mathrm{r}=0.46)$.

None of the participants was undergoing prophylactic treatment for migraine. More than half of them were unaware of this therapeutic option, while $45.5 \%$ of them had tried it, but did not persist with it. Eighty patients had previously received prophylaxis for migraine, but the attacks returned after treatment was withdrawn. Fifteen patients had not tolerated the adverse events of prophylaxis and had abandoned it, while another 15 had tried this therapeutic option without any improvement. Most patients (75\%) were not using more than five doses of migraine medication per month, while $5 \%$ used daily medication for pain. There was no correlation between catastrophization and the number of doses of medication used for migraine $(\mathrm{p}=0.55)$.

\section{DISCUSSION}

Patients with migraine can have difficulties in coping with the pain and may develop fearful and/or dramatic behavior regarding their headache attacks. Underlying anxiety and depression contribute towards reducing the ability to cope ${ }^{11}$. Having a migraine attack may be an important source of worry, and patients may overinterpret its burden. Pain catastrophizing relates to brain areas involved in pain processing, attention to pain, emotions, and reduced ability for pain inhibition $^{12}$. Ultimately, patients with chronic headache who have traits of anxiety and depression might be prone to catastrophize the attacks.

A recent Spanish study showed that about one third of patients with migraine had high degrees of catastrophization ${ }^{5}$.
In our study, we found that a similar proportion of our patients catastrophized to a high degree. The Spanish patients attended a tertiary headache clinic, while ours were from the general population. Therefore, we may infer that this behavior is found among individuals with migraine, irrespectively of the degree of care that the patients receive. Similar results have also been found in children and adolescents ${ }^{13}$ and in obese patients ${ }^{14}$.

Catastrophization did not show any correlation with the duration and intensity of pain, anxiety and depression, age, aura, frequency of attacks, or medication overuse. Because only a small number of men answered the survey, we could not evaluate the effect of gender on catastrophization. Among the other parameters, we were unable to make any moderate or strong correlation between catastrophization and any aspect of migraine. Catastrophization seems to be a trait of the individual and appears to be unrelated to the characteristics of the migraine. It is important to mention that a trend to rename 'pain catastrophizing' as 'pain-related worrying' has emerged recently ${ }^{15}$.

Our study had limitations. We did not have in-person contact with the participants and relied exclusively on the questionnaires. Some authors have criticized self-reported questionnaires for assessment of pain catastrophization, stating that this evaluation requires expert judgment ${ }^{15}$. In addition, the large number of women answering the questionnaires may reflect the fact that women are more likely to do so. Likewise, a high percentage of individuals with catastrophization behavior may reflect greater interest in this population in discussions about their headaches. In addition, more women than men have migraine. Dissemination on Facebook and Instagram meant we had no control of the locations where the study questionnaire was answered.

Lastly, the participants in our study were not receiving prophylactic treatment for their migraine. More than half of them were unaware of this therapeutic option, while $45.5 \%$ of them had tried it, but abandoned it. Over $16 \%$ of the participants could be classified as having chronic migraine and the fact that they were not undergoing treatment is worrisome.

In conclusion, the level of catastrophization in people with migraine appears to be more a trait of the individual than a characteristic related to the migraine.

\section{ACKNOWLEDGMENT}

Flavia R. Oliveira received a Scientific Initiation grant from Universidade Metropolitana de Santos.

\section{REFERENCES}

1. Peres MFP, Mercante JPP, Guendler VZ, Corchs F, Bernick MA,

Zukerman E, et al. Cephalalgiaphobia: a possible specific phobia of

illness. J Headache Pain. 2007 Feb;8(1):56ロ9. Kapoor S, Thorn BE,
Bandy O, Clements KL. Pain referents used to respond to the pain catastrophizing scale. Eur J Pain. 2015 Mar;19(3):400-7. https://doi. org/10.1002/ejp.561 
2. Kapoor S, Thorn BE, Bandy O, et al. Pain referents used to respond to the pain catastrophizing scale. Eur J Pain. 2015;19(3):400-7. https:// doi.org/10.1002/ejp.561

3. Severeijns R, Vlaeyen JW, van den Hout MA, Weber WE. Pain catastrophizing predicts pain intensity, disability, and psychological distress independent of the level of physical impairment. Clin J Pain. 2001 Jun;17(2):165-72. https://doi.org/10.1097/00002508200106000-00009

4. Bag B, Hacihasanoglu R, Tufekci FG. Examination of anxiety, hostility, and psychiatric disorders in patients with migraine and tensiontype headache. Int J Clin Pract. 2005 May;59(5):515-21. https://doi. org/10.1111/j.1368-5031.2005.00522.x

5. Alvarez-Astorga A, García-Azorín D, Hernández M, de la Red H, Sotelo $\mathrm{E}$, Uribe $\mathrm{F}$, et al. Pain catastrophising in a population of patients with migraine. Neurologia (Engl Ed). 2021 Jan-Feb;36(1):24-8. https://doi. org/10.1016/j.nrl.2018.10.005

6. International Headache Society. Headache classification committee of the international headache society (IHS) The international classification of headache disorders, 3rd edition. Cephalalgia. 2018 Jan;38(1):1-211. https://doi.org/10.1177/0333102417738202

7. Snaith RP. The hospital anxiety and depression scale. Health Qual Life Outcomes. 2003 Aug 1;1:29. https://doi.org/10.1186/1477-7525-29

8. Pais-Ribeiro J, Silva I, Ferreira T, Martins A, Meneses R, Baltar M. Validation study of a Portuguese version of the Hospital Anxiety and Depression Scale. Psychol Health Med. 2007 Mar;12(2):225-37. https://doi.org/10.1080/13548500500524088

9. Sullivan MJ, Bishop SR, Pivik J. The pain catastrophizing scale: development and validation. Psychol Assess. 1995;7(4):524-32. https://doi.org/10.1037/1040-3590.7.4.524

10. Sehn F, Chachamovich E, Vidor LP, Dall-Agnol L, Custódio de Souza IC, Torres ILS, et al. Cross-cultural adaptation and validation of the Brazilian Portuguese version of the pain catastrophizing scale. Pain Med. 2012 Nov;13(11):1425-35. https://doi.org/10.1111/j.15264637.2012.01492.x

11. Petrovics-Balog A, Majláth Z, Melinda L, Holczer A, Must A, Tajti $J$, et al. The effect of psychiatric comorbidities and stress-coping strategies on perceived quality of life in migraine. Ideggyogy Sz. 2019 Nov 30;72(11-12):397-404. https://doi.org/10.18071/ISZ.72.0397

12. Malfliet A, Coppieters I, Van Wilgen P, Kregel J, De Pauw R, Dolphens $M$, et al. Brain changes associated with cognitive and emotional factors in chronic pain: a systematic review. Eur J Pain. 2017 May;21(5):769-86. https://doi.org/10.1002/ejp.1003

13. Sciruicchio V, Simeone M, Barbaro MGF, Tanzi RC, Delussi MD, Libro G, et al. Pain catastrophizing in childhood migraine: an observational study in a tertiary headache center. Front Neurol. 2019 Feb 15;10:114. https://doi.org/10.3389/fneur.2019.00114

14. Bond DS, Buse DC, Lipton RB, Thomas JG, Rathier L, Roth J, et al. Clinical pain catastrophizing in women with migraine and obesity. Headache. 2015 Jul-Aug;55(7):923-33. https://doi.org/10.1111/ head.12597

15. Crombez G, De Paepe AL, Veirman E, Eccleston C, Verleysen G, Van Ryckeghem DML. Let's talk about pain catastrophizing measures: an item content analysis. Peer J. 2020 Mar 4;8:e8643. https://doi. org/10.7717/peerj.8643 